\title{
"Supply chain disruptions in the context of early stages of the global COVID-19
}

outbreak"

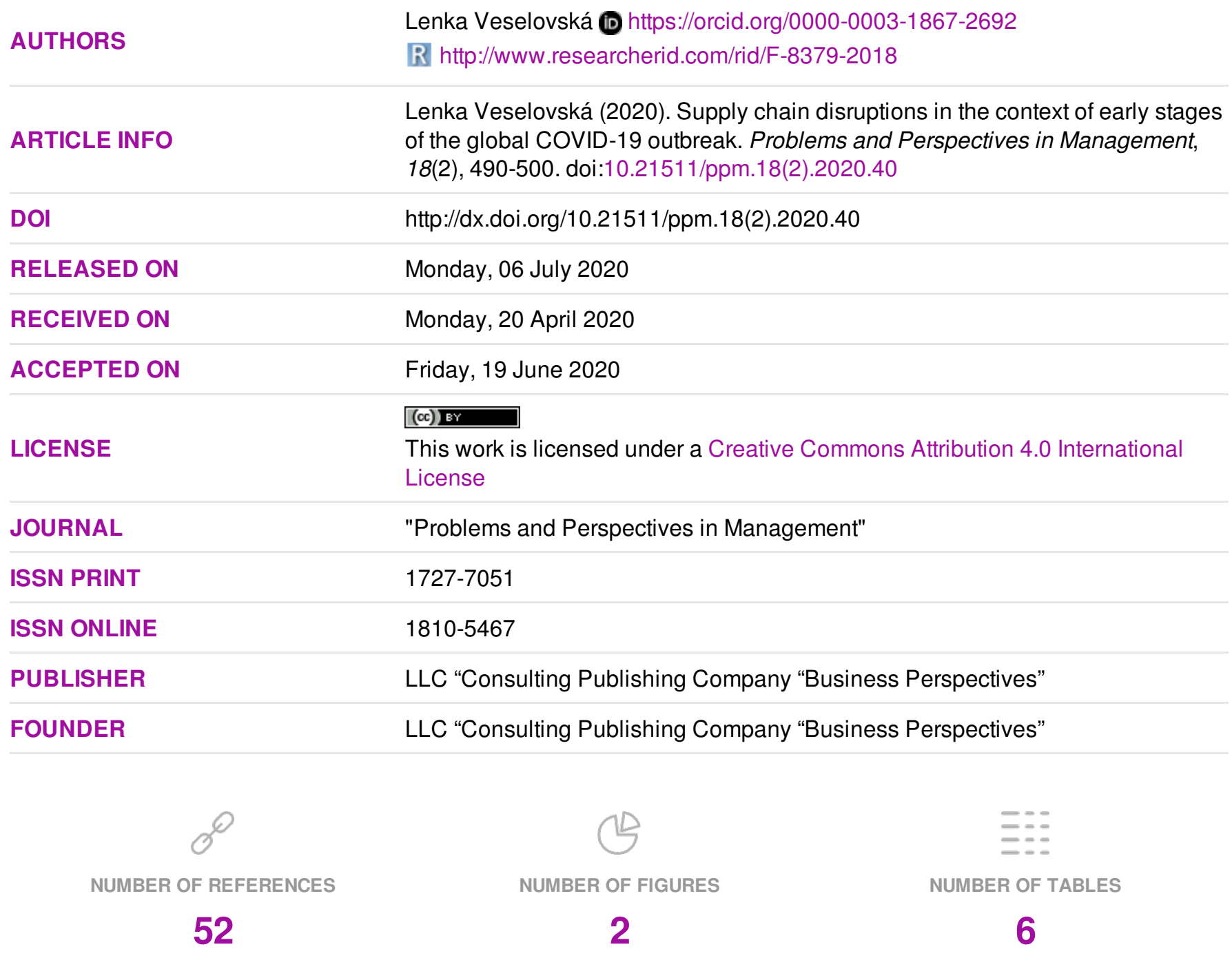

(c) The author(s) 2022. This publication is an open access article. 


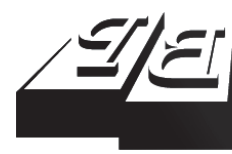

\section{BUSINESS PERSPECTIVES}

(O)

LLC "CPC "Business Perspectives" Hryhorii Skovoroda lane, 10, Sumy, 40022, Ukraine www.businessperspectives.org

Received on: $20^{\text {th }}$ of April, 2020 Accepted on: $19^{\text {th }}$ of June, 2020 Published on: $6^{\text {th }}$ of July, 2020

๑ Lenka Veselovská, 2020

Lenka Veselovská, Dr., Institute of Managerial Systems, Faculty of Economics, Matej Bel University in Banská Bystrica, Slovak Republic.

\section{SUPPLY CHAIN DISRUPTIONS IN THE CONTEXT OF EARLY STAGES OF THE GLOBAL COVID-19 OUTBREAK}

\begin{abstract}
The world finds itself facing unprecedented conditions as the global pandemic of the COVID-19 virus has led to fundamental changes in the global supply chains. This paper aims to assess the initial response undertaken by Central European companies in the early stages of the outbreak. The survey was conducted as a research method to collect data from a large number of companies. Since it takes time to assess long-term effects of the pandemic and related measures, various changes in supply chains are examined as the early results of the COVID-19 crisis and measures implemented by companies. The study examines how different economy sectors were changed due to this situation. The changes in operating volumes were identified as the most commonly used measures to accommodate new market developments. However, developing the new supply chain partnership was the most successful measure. This measure correlates with an increase in revenues and an increase in the number of customers. In some cases, disruptions in supply chains had positive effects on revenues as a reaction to the COVID-19 epidemic outbreak. Cross-country examinations found that all Polish companies implemented at least one new measure to tackle this crisis. Nearly $20 \%$ of Slovak companies and nearly 30\% of Czech companies made no changes in their operations during the early stages of the crisis. However, overall, the supply chains in Central European countries turned out to be quite resilient, since most companies managed to survive the supply chain disruptions and in some cases even show signs of overcoming them completely.
\end{abstract}

\section{Keywords}

COVID-19 implications, supply chain resilience, revenues, flexibility, Slovak Republic, Czech Republic, Hungary, Poland

JEL Classification F61, L21, O12, O52

\section{INTRODUCTION}

The world has been in unprecedented conditions, since the global pandemic of the COVID-19 virus brought fundamental changes in the global economy. This situation has highlighted the vulnerability and critical points of supply chains, many of which were not at all prepared to face such major disruptions. The reaction of companies in this context was also shaped with regard to the requirements of the chain restructuring. Although the recession that arose after the epidemic and the actions taken in response affected it to such an extent that it threatened their existence, many companies were able to cope with this situation and react flexibly. These examples clearly show that companies that pay sufficient attention to risk management and the flexibility of their supply chains can adapt more quickly and even gain a competitive advantage.

The closest example of a global pandemic of such scale can be found at the beginning of the last century. The 1918 Spanish Influenza Pandemic killed millions worldwide and unprecedentedly changed the economies (Clay, Lewis, \& Severnini, 2018; Matchim, 2019; Bristow, 
2013). The Spanish Influenza epidemic of 1918-1919 was the most horrible pandemic of contemporary era, claiming over 30 million lives in a few short months. The processes in societies were significantly disrupted. The magnitude of its impact on economic activities was massive. Some insights of its implications can be applied to many-sided complexity of a pandemic investigation (Hardy, 2006; Becker, 1981). However, the economies of developed states were not as interconnected as they are nowadays, and supply chains did not rely on the international trade on such a scale. Therefore, it can be concluded that there is no relevant precedence to current market conditions that can be used to draw comparisons and to rely on for guidance. On the other hand, much smaller and more localized disruptions had occurred in the past, and their effects on corresponding supply chains were examined and some conclusions can be used even nowadays as a foundation for research into the influence of the COVID-19 pandemic on the resilience and flexibility of supply chains.

Provided examples much in common in terms of the inevitable necessity to redesign supply chains to provide companies with much needed efficiency in the processes. Besides, the quick response of supply chains was identified as one of the key components of their survival. However, what is missing from the current pool of knowledge provided by literature so far is the role of the supply chain measures implemented as a response to this situation in overcoming such large-scale disruptions. This study seeks to provide answers to this question by examining the effects of COVID-19 measures on business activities and changes in supply chains using a risk management approach.

\section{LITERATURE REVIEW}

A new virus was noticed by the World Health Organization in the last month of 2019. In just two months, this infection has spread to all continents, except for Antarctica. Since then, information on the situation with COVID-19 has become daily news worldwide (McAleer, 2020; Danylyshyn, 2020). The COVID-19-related disruptions have the potential to significantly affect global supply chains. Even during the early stages of the pandemic, the impact of COVID-19 on the global supply chains has already become massive (Ivanov, 2020). The historical records show that major crises, including wars, famines, and pandemics, always bring significant changes to supply chains and may create long-term consequences for countries and their people (Sarkis, Cohen, Dewick, \& Schröder, 2020). Epidemic outbreaks are a particular example of supply chain risks, which is uniquely characterized by a long-term disruption of continued existence and high uncertainty. Since an epidemic disease outbreak poses a severe treat to people's existence, it always leads to a major crisis. To control the effects of such a crisis on the individual supply chain, the effective management must to quickly implement appropriate measures (Yu, Sun, Solvang, \& Zhao, 2020).

The examples of more current disasters and therefore scientific research can also be considered. The main event of $21^{\text {st }}$ century prior to the COVID-19 outbreak was the Fukushima Daiichi nuclear power plant disaster. Aside from the restoration costs, there were other implications for the local economy and international supply chains. Notably, consumers initially viewed harshly the food products originating from the Fukushima area after the 2011 Fukushima incident resulting in economic failures caused by the damaged images of companies (Matsumoto \& Hoang, 2019; Aruga, 2017). However, after disastrous supply chain disruptions even positive effects can appear over time, such as energy market reorganization in Japan after Fukushima (Goto \& Sueyoshi, 2016). The lessons from these analyses lie in knowing that funding the development has significant financial paybacks, and that retrospective effectiveness analysis can be used to study natural disaster responses undertaken by local governments and private companies (Vardon, Sassi, Zheng, \& Birur, 2019; Choi \& Lee, 2017; Managi \& Guan, 2017; Rehdanz, Welsch, Narita, \& Okubo, 2015).

The problem lies in identifying suitable measures and predicting their effectiveness since each such case is unique, and few similar examples can be found. Supply chain risks are multifaceted and can cause such disruptions that supply chains need to be completely redesigned (Chopra \& Sodhi, 2004; Cantor, Blackhurst, \& Cortes, 2014; Sodhi \& Tang, 
2012; Bartková, 2019). A few examples can already be found in a current pool of literature in specific sectors of economy. Gray (2020) found that "....in Canada the widespread implementation of social distancing has greatly augmented the need for food pickup and delivery services". The findings from his study include a significant need for constant supply chain assessment and the improvement of targeted policies to mitigate supply chain risks. Hobbs (2020) discovered that "...the COVID-19 pandemic will have longer-lasting impacts on the nature of food supply chains, including the expansion of the online grocery delivery sector, and the extent to which consumers will prioritize "local" food supply chains". Various authors (Bell \& Blanchflower, 2020; Jribi, Ben Ismail, Doggui, \& Debbabi, 2020) studied the effects on consumer behavior and labor markets. The COVID-19 disease is mainly a public health issue that impacts the food waste prevention behavior and negatively effects the employment in some economy sectors. Ivanov (2020) studied the framework of pandemics as a source of distinctive supply chain risks.

Risk management and supply chain management offer a vast range of possibilities to mitigate the effects of epidemic outbreak. However, such scenarios are yet to be tested in practices, especially their long-term effects. On the other hand, every example in practice shows that the key to overcome any major disruption is supply chain flexibility (Agarwal, Shankar, \& Tiwari, 2006; Gaimon \& Singhal, 1992; Das, 2011; Gong, 2008; Stevenson \& Spring, 2007). According to Peidro, Mula, Jiménez, and Botella (2010), organizations are forced to deal with multiple risks as a result of transformations that take place inside and around them. Implementing appropriate measures designed to adapt to these alterations is vital for their continued existence and key to discovering possible paths to success. In today's world, this also means developing efficient supply chains that are flexible and resilient (Datta \& Christopher, 2010). Different methods have been created to make supply chains more resilient and therefore more adaptable to changing environment (Lummus, Vokurka, \& Duclos, 2005). Flexibility can be considered as the goal of making a supply chain able to alter conditions to meet an unanticipated situation (Chuu, 2011). However, the resilience of supply chains during the COVID-19 crisis yet remains to be tested. This can be considered a research gap and an opportunity to develop considerable valuable information through research that can provide recommendations for both academics and managers in practice. This research study aims to contribute in such a way.

\section{METHODS}

The research study developed an evaluation of the COVID-19 outbreak changes and outcomes for supply chains of key sectors of economy. The main aim of this research was to examine disruptions and changes in supply chains of Central European countries caused by the COVID-19 crises. A survey was conducted to examine managers' opinions and their experiences in practice concerning the changes in supply chains due to either the COVID-19 pandemic itself or measures taken by governments as a response to the threat of virus. A questionnaire was send by e-mail to managers of 2,000 companies, 500 in each country. Nearly $11 \%$ of them provided a completed questionnaire. This research incorporated 211 international companies from four central European countries. The structure of a sample file is shown in Table 1.

Table 1. Structure of a sample file

\begin{tabular}{|c|c|c|c|c|c|c|c|c|c|c|}
\hline \multirow[b]{2}{*}{ Sample file } & \multicolumn{4}{|c|}{ Country of origin } & \multicolumn{6}{|c|}{ Business sector } \\
\hline & 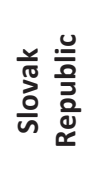 & 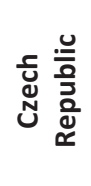 & \begin{tabular}{l} 
믐 \\
$\frac{\pi}{0}$ \\
\hdashline
\end{tabular} & 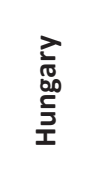 & 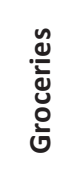 & $\frac{\text { du }}{2}$ & 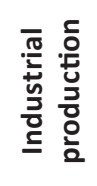 & 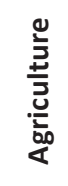 & 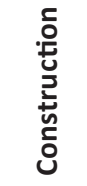 & 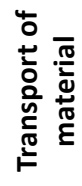 \\
\hline Number of companies & 61 & 54 & 47 & 49 & 14 & 51 & 79 & 6 & 27 & 34 \\
\hline Percentage (in \%) & 28.91 & 25.59 & 22.27 & 23.22 & 6.64 & 24.17 & 37.44 & 2.84 & 12.80 & 16.11 \\
\hline
\end{tabular}


Furthermore, 116 companies had less than 50 employees, which represents $54.98 \%$ of all companies in the sample file. On the other hand, 64 companies had more than 250 employees (30.33\%). Even though this file does not consist of such number of companies to be a representative sample of all companies in Central Europe, both its size and diversity offer an interesting source of information on researched topic in a relatively short period of time, which is extremely important for examining business reality and drawing up action plans to mitigate crises.

Several statistical tests were used to evaluate data. Firstly, Factor analysis was used to assess collected data and find which data can be used to examine the variables, as well as to determine the fundamental composition of the relationships among analyzed variables in a sample file. Various authors had already used this test (Hedges, Pacheco, \& Webber, 2014; Moretti, Anholon, Rampasso, Silva, Santa-Eulalia, \& Ignacio, 2019; Pop \& Pelau, 2017; Crede \& Harms, 2019; Phogat \& Gupta, 2019; Na-Nan, Chaiprasit, \& Pukkeeree, 2018; Veselovská, Závadský, \& Závadská, 2020) to cluster variables, which are notably correlated into factors, which can then direct the creations of novel complex factors that incorporate all the data in a more detailed approach. Binomial test was also used to evaluate the most common variable in the sample file. Spearman's Rank Correlation was calculated according to formula (1), where $n$ is the number of customers and $d$ represents the difference in the ranks:

$$
R_{S}=1-\left(\frac{6 \cdot \sum d^{2}}{n^{3}-n}\right)
$$

\section{RESULTS AND DISCUSSION}

Firstly, the changes in various supply chain characteristics were examined. Up to five types of supply chain structure were analyzed. Table 2 provides data on detected changes in the supply chain structure from 2019 to 2020.
Table 2. Changes in the supply chain structure

\begin{tabular}{|c|c|c|c|c|c|}
\hline \multicolumn{6}{|c|}{ Supply chain structure in 2019} \\
\hline & Divergent & Convergent & Serial & Dyadic & Network \\
\hline Divergent & 21 & 3 & 2 & 0 & 0 \\
\hline Convergent & 6 & 14 & 13 & 0 & 0 \\
\hline Serial & 14 & 31 & 62 & 1 & 0 \\
\hline Dyadic & 0 & 0 & 0 & 1 & 0 \\
\hline Network & 1 & 1 & 0 & 0 & 41 \\
\hline
\end{tabular}

According to Table 2, more than $65.87 \%$ of all companies have not observed any changes in their supply chain structure. On the other hand, most of changes were observed among divergent and convergent supply chain structures. In 2019, all companies with the network supply structure remain with this structure in 2020. However, two companies transformed their structure to network in 2020, when they previously had a different supply chain structure. Only two companies had a dyadic structure in 2019, out of which one remained unchanged, and the structure of the other one evolved to serial in 2020.

The other possibility to evaluate changes in the supply chain structure is through the number of its nodes, represented by the number of companies involved in the supply chain. Table 3 provides the corresponding data structured by two factors - country of origin and business sector. While the data based on the location did not prove any significant difference between the international supply chains, the segmentation by business sectors proved otherwise. The majority of companies selling groceries observed an increase in the number of their customers. On the other hand, almost no changes were observed in the supply chains of companies in the agricultural sector. Overall, most of all companies in the sample file (45.5\%) observed a decrease in the number of their customers due to COVID-19 measures. Only 5.69\% companies noted an increase in the number of their customers, which represents only 12 companies, most of which (9) are located in the Czech Republic. Over $20 \%$ of all companies observed a decrease in the number of their suppliers with the majority of them located in Slovakia (19). Furthermore, the highest rate of a decrease in the number of suppliers was among construction companies (66.67\%).

The changes in supply chains were also measured by changes in revenues of analyzed companies. 
Table 3. Changes in the number of supply chain nodes

\begin{tabular}{|c|c|c|c|c|c|c|c|c|c|c|}
\hline \multirow[b]{2}{*}{$\begin{array}{c}\text { Changes in the supply chain } \\
\text { structure (in \%) }\end{array}$} & \multicolumn{4}{|c|}{ Country of origin } & \multicolumn{6}{|c|}{ Business sector } \\
\hline & 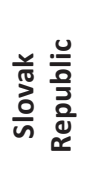 & 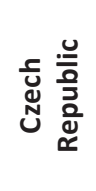 & $\begin{array}{l}\frac{D}{\frac{1}{0}} \\
\frac{\pi}{0} \\
0\end{array}$ & $\begin{array}{l}\frac{2}{\pi} \\
\frac{1}{00} \\
\frac{5}{3} \\
\text { I }\end{array}$ & 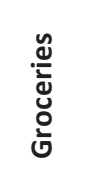 & $\frac{\stackrel{d}{u}}{\frac{u}{2}}$ & 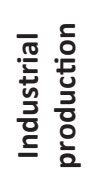 & $\frac{0}{\frac{0}{3}}$ & 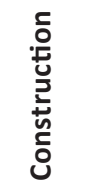 & 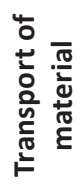 \\
\hline Decrease in the number of suppliers & 31.15 & 12.96 & 31.91 & 10.20 & 0.00 & 9.80 & 21.52 & 16.67 & 66.67 & 14.71 \\
\hline Increase in the number of suppliers & 3.28 & 3.70 & 29.79 & 28.57 & 0.00 & 17.65 & 13.92 & 0.00 & 0.00 & 35.29 \\
\hline Decrease in the number of customers & 55.74 & 66.67 & 25.53 & 28.57 & 7.14 & 68.63 & 63.29 & 0.00 & 0.00 & 29.41 \\
\hline Increase in the number of customers & 1.64 & 16.67 & 0.00 & 4.08 & 78.57 & 0.00 & 0.00 & 0.00 & 3.70 & 0.00 \\
\hline No change & 8.20 & 0.00 & 12.77 & 28.57 & 14.29 & 3.92 & 1.27 & 83.33 & 29.63 & 20.59 \\
\hline
\end{tabular}

Their managers were asked to compare between revenues in April 2019 and in April 2020. Several interesting findings can be observed (see Table 4). The data indicates that there was no decrease in revenues of grocery stores. Half of them even marked an increase of $26 \%-50$ in revenues. The situation was opposite in the sample of service companies. Only one such company marked no changes in revenues, whereas all others noted a decrease. Nearly $4 \%$ of them even observed a decrease over $75 \%$. The rate of change was the lowest among the production companies, since $51.89 \%$ observed no change in revenues, and 16 companies even observed an increase. Furthermore, revenue growth of more than $75 \%$ was observed by only one company in the entire sample. This company operated in transportation of cargo.

Moreover, $94.31 \%$ of supply chains contained international nodes in 2019. The number did not change significantly in 2020 (91.94\%), however, $78.35 \%$ of these companies reported disruptions in their supply chain processes due to delays or excessive handling at the borders. This factor was al- so implemented into the analysis. Figure 1 shows how the companies observed changes in their revenues based on disruptions in international supply chain nodes. All companies that observed revenue growth also observed disruptions in their international supply chains. The situation is the same with companies that noted either no change in revenues or a slight decrease of less than $25 \%$. However, the companies that experienced higher losses also did not observe disruptions as often as other companies. This finding is rather contradictory, since usually disruptions lead to financial losses; However, the situation during the initial periods of the COVID-19 crises seemed to be reversed for companies operating in Central Europe. Such controversial nature of this finding lead to further testing of these variables. Spearman's $R_{S}$ was calculated. Its value was at -0.461 . This result of a negative correlation coefficient further confirms that when company experienced disruptions in supply chain and managed to overcome them, its revenues were more likely to grow. In this study, there are no corresponding costs related to supply chain disruptions. However, the im-

Table 4. Changes in revenues based on business sector

\begin{tabular}{|c|c|c|c|c|c|c|}
\hline \multirow[b]{2}{*}{ Changes in revenues } & \multicolumn{6}{|c|}{ Business sector } \\
\hline & Groceries & Services & $\begin{array}{l}\text { Industrial } \\
\text { production }\end{array}$ & Agriculture & Construction & $\begin{array}{l}\text { Transport } \\
\text { of material }\end{array}$ \\
\hline No change & $7.14 \%$ & $1.96 \%$ & $51.90 \%$ & $33.33 \%$ & $29.63 \%$ & $11.76 \%$ \\
\hline Less than $25 \%$ decrease & $0.00 \%$ & $84.31 \%$ & $26.58 \%$ & $33.33 \%$ & $51.85 \%$ & $14.71 \%$ \\
\hline $26 \%-50 \%$ decrease & $0.00 \%$ & $3.92 \%$ & $1.27 \%$ & $0.00 \%$ & $3.70 \%$ & $14.71 \%$ \\
\hline $51 \%-75 \%$ decrease & $0.00 \%$ & $5.88 \%$ & $0.00 \%$ & $0.00 \%$ & $0.00 \%$ & $0.00 \%$ \\
\hline Over $75 \%$ decrease & $0.00 \%$ & $3.92 \%$ & $0.00 \%$ & $0.00 \%$ & $0.00 \%$ & $0.00 \%$ \\
\hline Less than $25 \%$ increase & $7.14 \%$ & $0.00 \%$ & $12.66 \%$ & $0.00 \%$ & $11.11 \%$ & $32.35 \%$ \\
\hline $26 \%-50 \%$ increase & $50.00 \%$ & $0.00 \%$ & $7.59 \%$ & $16.67 \%$ & $3.70 \%$ & $17.65 \%$ \\
\hline $51 \%-75 \%$ increase & $35.71 \%$ & $0.00 \%$ & $0.00 \%$ & $16.67 \%$ & $0.00 \%$ & $5.88 \%$ \\
\hline Over $75 \%$ increase & $0.00 \%$ & $0.00 \%$ & $0.00 \%$ & $0.00 \%$ & $0.00 \%$ & $2.94 \%$ \\
\hline
\end{tabular}




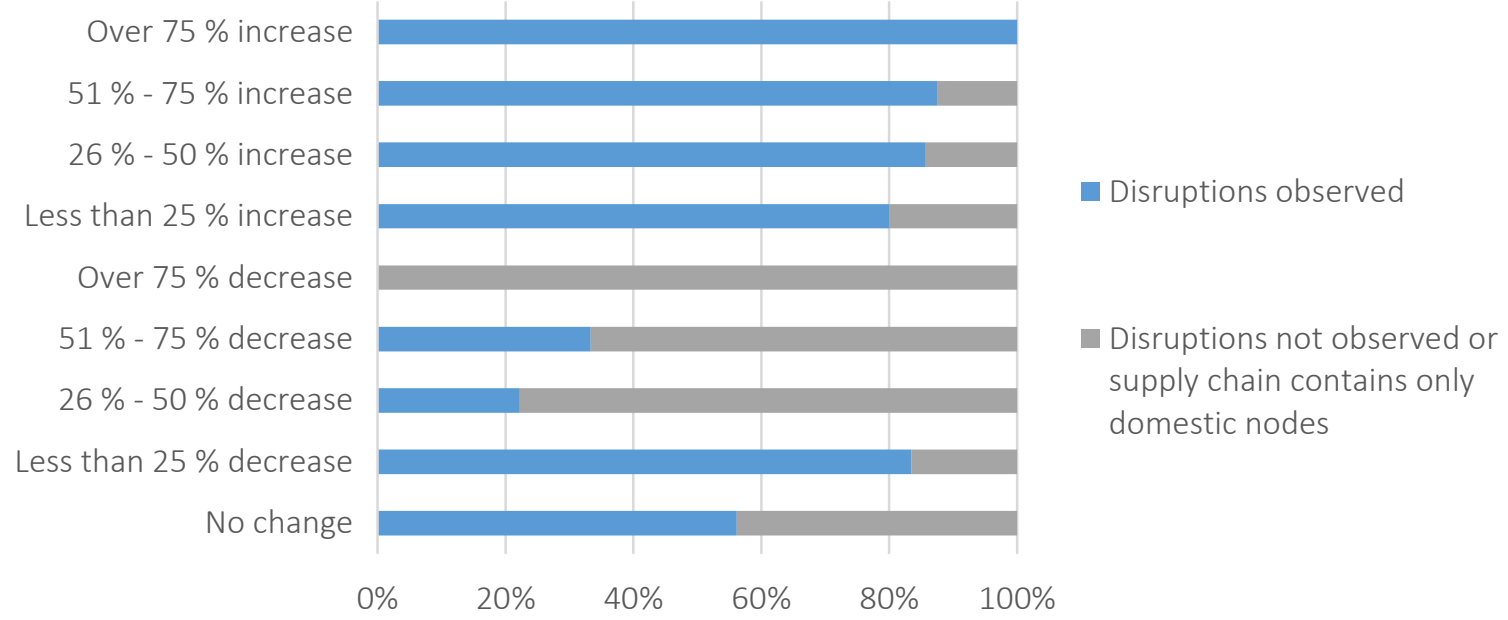

Figure 1. Changes in revenues based on disruptions in international supply chain nodes

plications of this finding lie mainly in implementing new measures to overcome this crisis, which provide an effective response. Furthermore, it can be concluded that most of supply chains were resilient enough to survive the disruptions and even overcome them. The supply chains of Central European companies were sufficiently prepared for this crisis.

Consequently, this finding was further evaluated in the context of possible localized differences among individual countries participating in the research. Therefore, Figure 2 shows distribution in international supply chain disruptions based on country of origin. According to the data, in fact there were significant differences among individual countries of Central Europe, especially in Hungary. The rate of disruptions in supply chain nodes was significantly higher in this country than in any of the other countries (95.92\%). The next highest rate was observed in Poland (74.47\%). In comparison, only $60.66 \%$ of Slovak companies experienced disruptions in international nodes of their supply chains. In Czech Republic, the rate was $61.11 \%$.
Furthermore, companies were asked to provide information on what initial measures they had implemented to successfully overcome the crises and respond to supply chain disruptions. The companies were presented with several options in the questionnaire and with the possibility of adding their own response. More than one option could be selected. Table 5 shows the results structured by country and business sector. Changes in the product mix and changes in operating volumes include both an increase and a decrease. The measure of new marketing promotion includes new campaigns and new promotion tools. Downsizing and recruiting represent changes in personnel. Companies were also provided with the option of no changes, which represented the implementation of no new measure during the early stages of the COVID-19 crisis; however, only 15.17\% of all companies decided not to implement any changes. Only one such company was operating in the service sector and none were grocery sellers. Moreover, none such companies were located in Poland. Half of grocery sellers had to recruit new personnel. On the other hand, more than $80 \%$ of production companies had to change their operat-

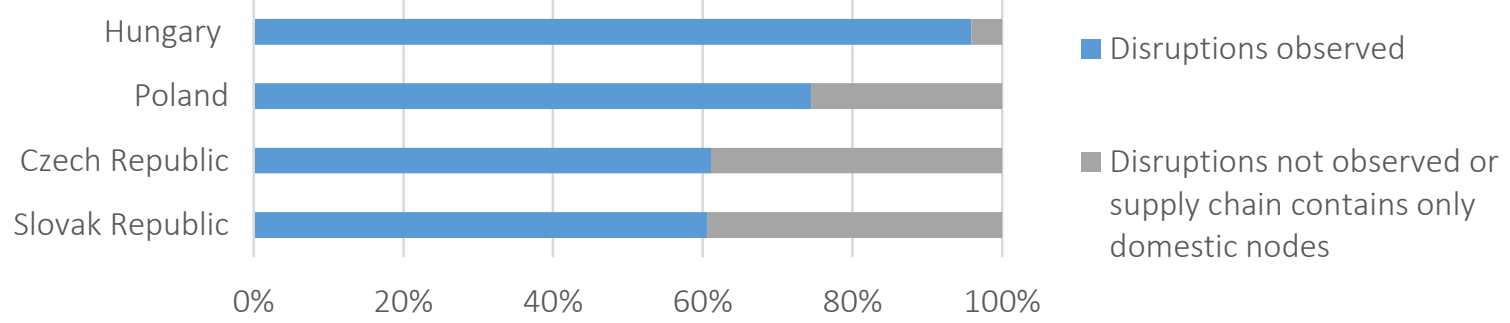

Figure 2. Disruptions in international supply chain nodes based on country of origin 
ing volumes due to the situation with COVID-19 and more than half of them had to reduce their personnel. No recruitment of new employees was introduced during this time in production companies. Interestingly, over $40 \%$ of these companies develop new strategic partnerships in their supply chains, which is by far the highest rate among companies from all business sectors, most of which were in Czech Republic (19 companies). The highest rate of changes in operating volumes was observed in Hungary since $91.84 \%$ of Hungarian companies introduced this measure. However, the utilization rates were also significant in other countries. Binomial test also confirmed that this was the most commonly introduced measure in the sample file. The results also show that the least affected industry of economy was the agricultural sector since half of companies operating in this sector did not need to implement new measures to cope with the crisis and the other half had to recruit new personnel. No other measures were introduced in this industry during the initial periods of the COVID-19 pandemic. Companies transporting materials were also not significantly affected since $41.18 \%$ of them also implemented no changes.

The introduction of measures can also be observed in the context of changes and disruptions in supply chains (Table 6). After implementing no new measures, 15 companies did not observe any changes in revenues and 12 companies did not observe any changes in supply chain structure. Interestingly, the companies with no new measures implemented are the only set in which there are fewer companies with observed disruptions in international supply chains than companies with no disruptions. Every other set of companies had the proportion reversed, since there were always more companies with supply chain disruptions than those without. On the other hand, none of the companies that did not implement any new measures during the initial stage of COVID-19 crisis managed to reach any increase in the number of their customers. Only $4.31 \%$ of companies that implemented cost reduction measures managed to achieve a revenue growth and $83.62 \%$ of them experienced a decrease, many of them simultaneously experienced a decrease in the number of suppliers and customers. Most of companies that needed to recruit new personnel experienced no changes in revenues $(80.65 \%)$ and none of them experienced any changes in the number of suppliers; as a matter of fact, more than one third of them observed an increase in the number of their customers. On the other hand, as expected, downsizing led mainly to negative results in revenues and in the number of supply chain partners. Despite implementing new promotion campaigns, $35.9 \%$ of companies observed a decrease in their revenues and $32.05 \%$ of them even a decrease in the number of their customers.

Table 5. Measures implemented as an initial response to the COVID-19 crisis

\begin{tabular}{|c|c|c|c|c|c|c|c|c|c|c|}
\hline \multirow[b]{2}{*}{ Implemented measure (in \%) } & \multicolumn{4}{|c|}{ Country of origin } & \multicolumn{6}{|c|}{ Business sector } \\
\hline & 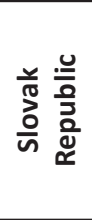 & 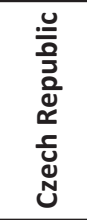 & $\begin{array}{l}\frac{0}{1} \\
\frac{1}{10} \\
0 \\
0\end{array}$ & $\begin{array}{l}\frac{7}{7} \\
\sqrt[0]{0} \\
0 \\
\frac{5}{3} \\
\text { T }\end{array}$ & 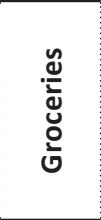 & $\frac{\mathscr{d}}{\frac{u}{2}}$ & 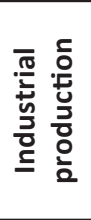 & $\frac{0}{\frac{0}{3}}$ & 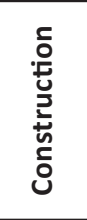 & 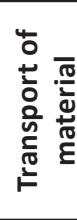 \\
\hline Changes in product mix & 42.62 & 40.74 & 29.79 & 8.16 & 100.00 & 74.51 & 2.53 & 0.00 & 11.11 & 26.47 \\
\hline Changes in operating volumes & 63.93 & 46.30 & 78.72 & 91.84 & 92.86 & 98.04 & 86.08 & 0.00 & 25.93 & 23.53 \\
\hline New marketing promotion & 22.95 & 70.37 & 40.43 & 14.29 & 100.00 & 84.31 & 2.53 & 0.00 & 44.44 & 20.59 \\
\hline Downsizing & 37.70 & 50.00 & 76.60 & 55.10 & 0.00 & 82.35 & 59.49 & 0.00 & 37.04 & 41.18 \\
\hline Recruiting & 19.67 & 14.81 & 10.64 & 12.24 & 50.00 & 1.96 & 0.00 & 50.00 & 44.44 & 23.53 \\
\hline Cost reduction & 40.98 & 62.96 & 65.96 & 53.06 & 7.14 & 62.75 & 51.90 & 0.00 & 85.19 & 55.88 \\
\hline New supply chain partnership development & 18.03 & 35.19 & 14.89 & 0.00 & 14.29 & 0.00 & 41.77 & 0.00 & 0.00 & 5.88 \\
\hline Payments renegotiations and postponements & 59.02 & 74.07 & 55.32 & 26.53 & 35.71 & 74.51 & 51.90 & 0.00 & 88.89 & 20.59 \\
\hline New discounts introduction & 18.03 & 27.78 & 53.19 & 34.69 & 0.00 & 70.59 & 18.99 & 0.00 & 29.63 & 26.47 \\
\hline No changes & 19.67 & 29.63 & 0.00 & 8.16 & 0.00 & 1.96 & 13.92 & 50.00 & 11.11 & 41.18 \\
\hline
\end{tabular}


Table 6. Measures implemented in the context of changes and disruptions in supply chains

\begin{tabular}{|c|c|c|c|c|c|c|c|c|c|c|}
\hline \multirow[b]{2}{*}{$\begin{array}{l}\text { Implemented measure } \\
\text { (in \%) }\end{array}$} & \multicolumn{3}{|c|}{ Changes in revenues } & \multicolumn{2}{|c|}{$\begin{array}{l}\text { Disruptions in } \\
\text { international } \\
\text { supply chain } \\
\text { nodes }\end{array}$} & \multicolumn{5}{|c|}{ Changes in supply chain structure } \\
\hline & 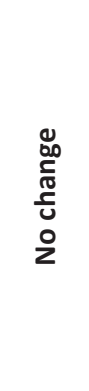 & 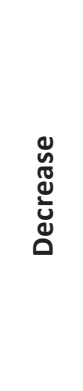 & 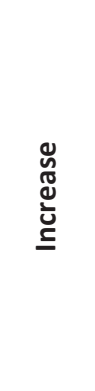 & 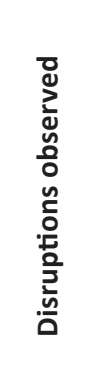 & 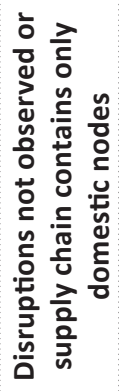 & 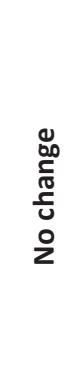 & 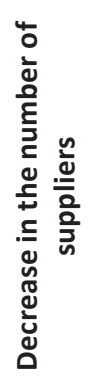 & 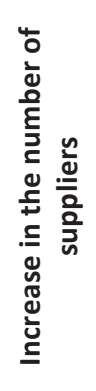 & 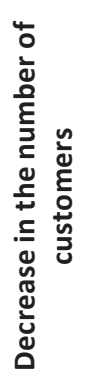 & 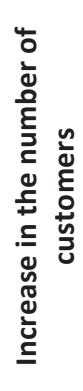 \\
\hline Changes in product mix & 7.58 & 46.97 & 45.45 & 98.48 & 1.52 & 10.61 & 36.36 & 42.42 & 9.09 & 1.52 \\
\hline Changes in operating volumes & 34.93 & 51.37 & 13.70 & 88.36 & 11.64 & 17.12 & 28.77 & 8.22 & 37.67 & 8.22 \\
\hline New marketing promotion & 17.95 & 35.90 & 46.15 & 73.08 & 26.92 & 17.95 & 11.54 & 23.08 & 32.05 & 15.38 \\
\hline Downsizing & 10.62 & 85.84 & 3.54 & 94.69 & 5.31 & 15.93 & 23.89 & 2.65 & 52.21 & 5.31 \\
\hline Recruiting & 80.65 & 3.23 & 16.13 & 93.55 & 6.45 & 48.39 & 0.00 & 0.00 & 16.13 & 35.48 \\
\hline Cost reduction & 12.07 & 83.62 & 4.31 & 53.45 & 46.55 & 1.72 & 38.79 & 1.72 & 47.41 & 10.34 \\
\hline $\begin{array}{l}\text { New supply chain partnership } \\
\text { development }\end{array}$ & 5.41 & 54.05 & 40.54 & 100.00 & 0.00 & 0.00 & 2.70 & 43.24 & 16.22 & 37.84 \\
\hline $\begin{array}{l}\text { Payments renegotiations and } \\
\text { postponements }\end{array}$ & 40.87 & 48.70 & 10.43 & 68.70 & 31.30 & 4.35 & 12.17 & 6.09 & 77.39 & 0.00 \\
\hline New discounts introduction & 17.65 & 61.76 & 20.59 & 85.29 & 14.71 & 35.29 & 25.00 & 20.59 & 5.88 & 13.24 \\
\hline No changes & 46.88 & 21.88 & 31.25 & 34.38 & 65.63 & 37.50 & 18.75 & 9.38 & 34.38 & 0.00 \\
\hline
\end{tabular}

\section{CONCLUSION}

The research conducted on a sample of Central European companies focused on examining the disruptions in supply chains caused by the COVID-19 global pandemic. The contribution of this study lies mainly in describing the specific measures taken during the early stages of the outbreak by companies in various countries, as well as their initial results in the form of changes in revenues and supply chain characteristics. The findings indicate that some companies were able to adapt their supply chains to modified conditions in the early stages of the COVID-19 crisis in such a way that even led to an increase in their revenues. However, other companies struggled more. There were no significant differences among countries concerning the supply chain disruptions with the exception of Hungarian companies, which clearly struggled more. More than a third of companies experienced such significant disruptions that forced them to redesign their supply chains, which even resulted in differences in structures.

For many companies, this crisis provided an opportunity to gain more customers and even develop a competitive advantage. Such companies were mostly from a pool of grocery sellers that benefited from initial closures of restaurants and gained customers who, instead of eating out, decided to buy raw materials and cook at home. Similarly, in Canada, COVID-19 created a new set of challenges in the agricultural and grocery sellers sectors. Almost instantly, nearly $30 \%$ of the money spent on food away from home shifted to grocery sellers (Goddard, 2020). Services suffered the most because this sector depended on direct contact with a customer, which was not possible on a large scale, since in many countries measures were taken regarding social distance. Other authors also focused on this sector and provided evidence similar to the results obtained in the current study (Higgins-Desbiolles, 2020). Agricultural sector in Central Europe was not as affected as other sectors of the economy. Even, Weersink, von Massow, and McDougall (2020) state that this supply management sector is more resilient and can better deal with negative effects and disruptions of COVID-19 than other sectors, since agricultural producers are usually more economically 
constant, and some management functions, such as marketing, are synchronized. Other authors focused on examining the effect of external disruptions on supply chain (Sodhi \& Lee, 2007; Ivanov, 2020; Nicola, Alsafi, Sohrabi, Kerwan et al., 2020; Závadský \& Závadská, 2014; Mackelprang, Robinson, Bernardes, \& Webbl, 2014; Duginets, 2020). Some of them even drew conclusions similar to findings obtained in this research, however, none of them operated under the circumstances of global pandemic and, therefore, the comparison of research findings is possible only in a limited way.

Since this research and all other research studies (Ataguba, 2020; Pirouz, Haghshenas, Sina S., Haghshenas, Sami S., \& Piro, 2020; Yu, Sun, Solvang, \& Zhao, 2020; McAleer, 2020; Huynh, 2020; Sarkis, Cohen, Dewick, \& Schröder, 2020) were conducted in the early stages of the crisis, the success of measures taken cannot be precisely quantified. The adequacy of each response has to be measured after a certain period of time, at least after one year, to provide correct findings regarding the success or failure of individual response taken by companies. However, it is clear that none of the companies that did not take any new measures in the initial stage of the COVID-19 crisis managed to reach an increase in the number of their customers. Therefore, it can be concluded that any response made by companies in the initial stages of the crisis will only be beneficial in the long term. The findings of this research can be used by managers in practice to identify and develop effective measures to be implemented during this crisis based on the experience of other companies and the initial impact of the COVID-19 outbreak on supply chains and related plans. This study may also help identify successful and effective risk management measures during epidemic outbreaks.

\section{AUTHOR CONTRIBUTIONS}

Conceptualization: Lenka Veselovská.

Data curation: Lenka Veselovská.

Formal analysis: Lenka Veselovská.

Investigation: Lenka Veselovská.

Methodology: Lenka Veselovská.

Software: Lenka Veselovská.

Validation: Lenka Veselovská.

Visualization: Lenka Veselovská.

Writing - original draft: Lenka Veselovská.

Writing - review \& editing: Lenka Veselovská.

\section{ACKNOWLEDGEMENT}

This contribution was supported by the project No. 1/0757/18, "Consumer behavior in buying goods of daily consumption with an emphasis placed different contents of goods offered on markets of selected EU countries".

\section{REFERENCES}

1. Agarwal A., Shankar, R., \& Tiwari, M. K. (2006). Modeling the metrics of lean, agile and leagile supply chain: An ANP-based approach. European Journal of Operational Research, 173(1), 211-225. https://doi.org/10.1016/j. ejor.2004.12.005

2. Ataguba, J. E. (2020). COVID-19 Pandemic, a War to be Won: Understanding its Economic Implica- tions for Africa. Applied Health Economics and Health Policy, 18, 325-328. https://doi.org/10.1007/ s40258-020-00580-x

3. Atruga, K. (2017). Consumer responses to food produced near the Fukushima nuclear plant. Environmental Economics and Policy Studies, 19(4), 677-690. https://doi. org/10.1007/s10018-016-0169-y
4. Bartková, L. (2019). How do consumers perceive the dual quality of goods and its economic aspects in the European Union? An empirical study. Problems and Perspectives in Management, 17(3), 382-394. http://doi.org/10.21511/ ppm.17(3).2019.31

5. Becker, J. J. (1981). 20-milliondead + worldwide epidemic 
- Spanish influenza took its toll. Histoire, 40, 82-83.

6. Bell, D. N. F., \& Blanchflower, D. G. (2020). US and UK Labor Markets before and during the COVID-19 crash. National Institute Economic Review, 252, R52-R69. https://doi. org/10.1017/nie.2020.14

7. Bristow, N. K. (2013). Mark Osborne Humphries, The Last Plague: Spanish Influenza and the Politics of Public Health in Canada. Social History of Medicine, 26(4), 782-783. https://doi.org/10.1093/shm/hkt056

8. Cantor, D. E., Blackhurst, J. V., \& Cortes, J. D. (2014). The clock is ticking: The role of uncertainty, regulatory focus, and level of risk on supply chain disruption decision making behavior. Transportation Research Part E: Logistics and Transportation Review, 72, 159172. https://doi.org/10.1016/j. tre.2014.10.007

9. Choi, J., \& Lee, S. (2017). Managing a crisis: A framing analysis of press releases dealing with the Fukushima nuclear power station crisis. Public Relations Review, 43(5), 1016-1024. https://doi.org/10.1016/j. pubrev.2017.09.004

10. Chopra S., \& Sodhi, M. S. (2004). Managing Risk to Avoid Supply Chain Breakdown. MIT Sloan Management Review, 46(1), 53-61. Retrieved from https:// www.researchgate.net/publication/237646139_Managing_Risk_ to_Avoid_Supply-Chain_Breakdown

11. Chuu, S.-J. (2011). Interactive group decision-making using a fuzzy linguistic approach for evaluating the flexibility in a supply chain. European Journal of Operational Research, 213(1), 279-289. https:// doi.org/10.1016/j.ejor.2011.03.022

12. Clay, K., Lewis, J., \& Severnini, E. (2018). Pollution, Infectious Disease, and Mortality: Evidence from the 1918 Spanish Influenza Pandemic. Journal of Economic History, 78(4), 1179-1209. https://doi.org/10.1017/ S002205071800058X

13. Crede, M., \& Harms, P. (2019). Questionable research practices when using confirmatory factor analysis. Journal of Managerial
Psychology, 34(1), 18-30. https://doi. org/10.1108/JMP-06-2018-0272

14. Danylyshyn, B. (2020). The peculiarities of economic crisis due to COVID-19 pandemic in a developing country: case of Ukraine. Problems and Perspectives in Management, 18(2), 13-22. https://doi. org/10.21511/ppm.18(2).2020.02

15. Das, K. (2011). Integrating effective flexibility measures into a strategic supply chain planning model. European Journal of Operational Research, 211(1), 170-183. https:// doi.org/10.1016/j.ejor.2010.12.006

16. Datta, P. P., \& Christopher, M. G. (2010). Information sharing and coordination mechanisms for managing uncertainty in supply chains: a simulation study. International Journal of Production Research, 49(3), 765-803. https://doi. org/10.1080/00207540903460216

17. Duginets, G. (2020). Global imperatives for development of international production networks: case of Ukraine. Problems and Perspectives in Management, 18(1), 57-69. https://doi.org/10.21511/ ppm.18(1).2020.06

18. Gaimon, C., \& Singhal, V. (1992). Flexibility and the choice of manufacturing facilities under short product life cycles. European Journal of Operational Research, 60(2), 211223. https://doi.org/10.1016/03772217(92)90094-P

19. Goddard, E. (2020). The impact of COVID-19 on food retail and food service in Canada: Preliminary assessment. Canadian Journal of Agricultural Economics - Revue Canadienne D'Agroeconomie, Article in press. https://doi.org/10.1111/ cjag. 12243

20. Gong, Z. (2008). An economic evaluation model of supply chain flexibility. European Journal of Operational Research, 184(2), 745-758. https://doi.org/10.1016/j. ejor.2006.11.013

21. Goto, M., \& Sueyoshi, T. (2016). Electricity market reform in Japan after Fukushima. Economics of Energy \& Environmental Policy, 5(1), 15-30. Retrieved from https://ideas. repec.org/a/aen/eeepjl/eeep5-1-goto. html
22. Gray, R.S. (2020). Agriculture, transportation, and the COVID-19 crisis. Canadian Journal of Agricultural Economics - Revue Canadienne D'Agroeconomie, Article in press. https://doi.org/10.1111/cjag.12235

23. Hardy, A. (2006). The Spanish influenza pandemic of 1918-19: New perspectives. European History Quarterly, 36(4), 641-643. https:// doi.org/10.1177/0265691406068194

24. Hedges, M. R., Pacheco, G. A., \& Webber, D. J. (2014). What determines students' choices of elective modules? International Review of Economics Education, 17, 39-54. https://doi.org/10.1016/j. iree.2014.05.003

25. Higgins-Desbiolles, F. (2020). Socialising tourism for social and ecological justice after COVID-19. Tourism Geographies. Article in press. https://doi.org/10.1080/14616 688.2020.1757748

26. Hobbs, J. E. (2020). Food supply chains during the COVID-19 pandemic. Canadian Journal of Agricultural Economics - Revue Canadienne D'Agroeconomie, Article in press. https://doi.org/10.1111/ cjag. 12237

27. Huynh, T. L. D. (2020). The COVID-19 risk perception: A survey on socioeconomics and media attention. Economics Bulletin, 40(1), 758-764. Retrieved from http://www. accessecon.com/Pubs/EB/2020/Volume40/EB-20-V40-I1-P64.pdf

28. Ivanov, D. (2020). Predicting the impacts of epidemic outbreaks on global supply chains: A simulation-based analysis on the coronavirus outbreak (COVID-19/ SARS-CoV-2) case. Transportation Research Part E-Logistics and Transportation Review, 136. https://doi. org/10.1016/j.tre.2020.101922

29. Jribi, S., Ben Ismail, H., Doggui, D., \& Debbabi, H. (2020). COVID-19 virus outbreak lockdown: What impacts on household food wastage? Environment Development and Sustainability, 22(5), 3939-3955. https://doi.org/10.1007/s10668-02000740-y

30. Lummus, R. R., Vokurka, R. J., \& Duclos, L. K. (2005). Delphi study on supply chain flexibility. Interna- 
tional Journal of Production Research, 43(13), 2687-2708. https://doi. org/10.1080/00207540500056102

31. Mackelprang, A. W., Robinson, J. L., Bernardes, E., \& Webb, G. S. (2014) The Relationship Between Strategic Supply Chain Integration and Performance: A Meta-Analytic Evaluation and Implications for Supply Chain Management Research. Journal of Business Logistics, 35(1), 71-96. https://doi.org/10.1111/jbl.12023

32. Managi, S., \& Guan, D. (2017). Multiple disasters management: Lessons from the Fukushima triple events. Economic Analysis and Policy, 53, 114-122. https://doi.org/10.1016/j. eap.2016.12.002

33. Matchim, J. R. (2019). We All Expected to Die: Spanish Influenza in Labrador, 1918-1919. Canadian Historical Review, 100(4), 676-677. https://doi.org/10.3138/ chr.100.4.br13

34. Matsumoto, S., \& Hoang, V.-N. (2019). Economic Loss Due to Reputation Damage: A New Model and Its Application to Fukushima Peaches. Journal of Agricultural Economics, 71(21). https://doi. org/10.1111/1477-9552.12366

35. McAleer, M. (2020). Prevention Is Better Than the Cure: Risk Management of COVID-19. Journal of Risk and Financial Management, 13(3). https://doi.org/10.3390/ jrfm13030046

36. Moretti, E. D., Anholon, R., Rampasso, I. S., Silva, D., Santa-Eulalia, L. A., \& Ignacio, P. S. D. (2019). Main difficulties during RFID implementation: an exploratory factor analysis approach. Technology Analysis \& Strategic Management, 31(8), $943-$ 956. https://doi.org/10.1080/095373 25.2019.1575351

37. Na-Nan, K., Chaiprasit, K., \& Pukkeeree, P. (2018). Factor analysis-validated comprehensive employee job performance scale. International Journal of Quality \& Reliability Management, 35(10), 2436-2449. https://doi.org/10.1108/ IJQRM-06-2017-0117

38. Nicola, M., Alsafi, Z., Sohrabi, C., Kerwan, A., Al-Jabir, A., Iosifidis, C., Agha, M., \& Agha, R. (2020). The Socio-Economic Implications of the Coronavirus and COVID-19 Pandemic: A Review. International Jour- nal of Surgery, 78, 185-193. https:// doi.org/10.1016/j.ijsu.2020.04.018

39. Peidro, D., Mula, J., Jiménez, M., \& Botella, M. M. (2010). A fuzzy linear programming based approach for tactical supply chain planning in an uncertainty environment. European Journal of Operational Research, 205(1), 65-80. http://doi. org/10.1016/j.ejor.2009.11.031

40. Phogat, S., \& Gupta, A. K. (2019). Evaluating the elements of just in time (JIT) for implementation in maintenance by exploratory and confirmatory factor analysis. International Journal of Quality $\&$ Reliability Management, 36(1), 7-24. https://doi.org/10.1108/ IJQRM-12-2017-0279

41. Pirouz, B., Haghshenas, Sina S., Haghshenas, Sami S., \& Piro, P. (2020). Investigating a Serious Challenge in the Sustainable Development Process: Analysis of Confirmed cases of COVID-19 (New Type of Coronavirus) Through a Binary Classification Using Artificial Intelligence and Regression Analysis. Sustainability, 12(6), 2427. https://doi.org/10.3390/su12062427

42. Pop, N. A., \& Pelau, C. (2017). Correlations within the EFQM Business Excellence Model by Applying a Factor Analysis. Amfiteatru Economic, 19(44), 28-40. Retrieved from https://www.researchgate.net/ publication/314520174_Correlations_within_the_EFQM_Business Excellence_Model_by_Applying_a_ Factor_Analysis

43. Rehdanz, K., Welsch, H., Narita, D., \& Okubo, T. (2015). Well-being effects of a major natural disaster: The case of Fukushima. Journal of Economic Behavior \& Organization, 116 500-517. https://doi.org/10.1016/j. jebo.2015.05.014

44. Sarkis, J., Cohen, M. J., Dewick, P., \& Schröder, P. (2020). A brave new world: Lessons from the COVID-19 pandemic for transitioning to sustainable supply and production. Resources, Conservation \& Recycling, 159, 104894 https://doi.org/10.1016/j.resconrec.2020.104894

45. Sodhi, M. S., \& Lee, S. (2007). An analysis of sources of risk in the consumer electronics industry. Journal of Operational Research
Society, 58(11), 1430-1439. https://doi.org/10.1057/palgrave. jors. 2602410

46. Sodhi, M. S., \& Tang, C. S. (2012). Strategic approaches for mitigating supply chain risks. International Series in Operations Research \& Management Science, 172(1), 95-108. https://doi.org/10.1007/978-1-46143238-8_7

47. Stevenson, M., \& Spring, M. (2007) Flexibility from a supply chain perspective: definition and review. International Journal of Operations \& Production Management, 27(7), 685-713. https://doi. org/10.1108/01443570710756956

48. Vardon, P., Sassi, A., Zheng, Y., \& Birur, D. (2019). Fukushima: U.S. Response and the Short-Term Impact on U.S.-Japan Trade in Fish and Seafood. Journal of Benefit-Cost Analysis, 10(3), 351-378. https://doi. org/10.1017/bca.2019.19

49. Veselovská, L., Závadský, J., \& Závadská, Z. (2020). Mitigating bribery risks to strengthen the corporate social responsibility in accordance with the ISO 37001. Corporate Social Responsibility and Environmental Management. Article in press. https://doi.org/10.1002/ csr.1909

50. Weersink, A., von Massow, M., \& McDougall, B. (2020). Economic thoughts on the potential implications of COVID-19 on the Canadian dairy and poultry sectors. Canadian Journal of Agricultural Economics - Revue Canadienne D'Agroeconomie, Article in press. https://doi.org/10.1111/cjag.12240

51. Yu, H., Sun, X., Solvang, W. D., \& Zhao, X. (2020). Reverse Logistics Network Design for Effective Management of Medical Waste in Epidemic Outbreaks: Insights from the Coronavirus Disease 2019 (COVID-19) Outbreak in Wuhan (China). International Journal of Environmental Research and Public Health, 17(5), 1770. https://doi. org/10.3390/ijerph17051770

52. Závadský, J., \& Závadská, Z. (2014). Utilisation of business process models in managerial practice: An empirical study in Slovak companies certified to the ISO 9001 standard. Total Quality Management \& Business Excellence, 24(3-4), 319337. https://doi.org/10.1080/147833 63.2013.791103 